\title{
From Networking To Nepotism: Systemic Racism And The Paradox Of Academic Networks
}

\author{
Jane-Frances Lobnibe \\ University For Development Studies-Ghana
}

\begin{abstract}
The phrase "it's who you know, not what you know that counts" is often heard in conversations about people who get ahead. In academic circles, this concept translates into what is often called "networking". The daily life of the graduate student in US universities hinges on the individual's ability to interact and form strategic alliances with other members of the academy. Indeed, networking is a widely accepted norm within higher education and commonly practiced by well meaning progressive scholars in the academy; but few, if any, have examined the ability of such a practice to exclude certain groups and individual students from active academic participation. It is very common to hear scholars' advice students and especially junior faculty, to try to "network" with particularly the "well connected" and "powerful" scholars in their fields of study. But what exactly does networking entail? What are the factors that influence people's networking practices and how do these factors favor or disadvantage individuals or groups in the networking process? This paper examines how systemic racism influences networking practices in US colleges and Universities and how that affects the lived experiences of female African students at a major research university in the US. , I focus on the racialized nature and paradoxes of "networking" in higher education in order to show that such an idea and practice contribute and or form part of the institutional structure that works to oppress, dominate and marginalize racial minority groups and individuals within the academy. I argue that the idea of "networking" in higher education is yet another name for intellectual "nepotism" within the context of systemic racism.
\end{abstract}

Key Words: International Students, Higher Education, Nepotism, Systemic Racism, Networking.

\section{INTRODUCTION}

Indeed, networking is a widely accepted norm within higher education and commonly practiced by well meaning progressive scholars in the academy; but few, if any, have examined the ability of such a practice to exclude certain groups and individual students from active academic participation. It is very common to hear scholars' advice students and especially junior faculty, to try to "network" with particularly the "well connected" and "powerful" scholars in their fields of study. But what exactly does networking entail? What are the factors that influence people's networking practices and how do these factors favor or disadvantage individuals or groups in the networking process? This paper examines how systemic racism influences networking practices in US colleges and Universities and how that affects the lived experiences of female African students at a major research university in the US. , I focus on the racialized nature and paradoxes of "networking" in higher education in order to show that such an idea and practice contribute and or form part of the institutional structure that works to oppress, dominate and marginalize racial minority groups and individuals within the academy. I argue that the idea of "networking" in higher education is yet another name for intellectual "nepotism" within the context of systemic racism. 
The significance of this problem lies in its contribution to our understanding of how social and institutional structures (characterized by systemic racism) within US colleges affect the nature of international students' experiences in these institutions. Considering the changing demographics of contemporary higher education institutions in the United States, and the emphasis universities place on internationalizing and diversifying their institutions, it is important that we understand the differential impacts of certain norms and practices within our schools on different populations that we admit.

The purpose of this paper is to turn the discussion about international students' experiences in US institutions away from individual students' cultural and interpersonal differences to focus on the institutional structures that place them in certain locations within our schools. The aim here is to examine how systemic racism influences the nature of international students' interaction with their peers, professors and academic staff in their host institutions and the impact of that in their networking practices.

In pursuing the following objectives, I ask the following questions; what and how is networking practiced in academic institutions? How does systemic racism affect the process of networking for racial minorities like female African graduate students and how do they negotiate/navigate the process of networking in their academic and social interactions? Answering these questions ultimately address the underlying assumptions, nature and implications of networking for specific groups of students in higher education.

\section{RESEARCH ON INTERNATIONAL STUDENTS' EXPERIENCE.}

There is no gainsaying that higher education has increasingly become international, and foreign students are among the visible elements of this internationalism. A significant change in contemporary higher education is a substantial increase in the number of international students (IS) in the United States. Attracting international students has become a priority for U.S. universities regardless of size or location. In fact, in this era of globalization ${ }^{1}$ and also in the face of dwindling public funding of higher education and declining home student enrollments especially in post graduate studies in certain fields, many universities and colleges in the United States are making great efforts to develop and expand international activities, study abroad programs and student and faculty exchange programs not just for the tuition dollars international students bring in to keep universities alive, but also for the cultural diversity they bring to campus. But one has to ask, what it is like for international students to study in US higher education institutions? How do they negotiate and navigate the complex structures within these institutions that are often marked by institutional racism?

Indeed, current research on international students' experiences pursuing higher education in the US, has yielded a large body of literature that tends to concentrate on one or more discrete elements of adjustment issues-- coping strategies, social-cultural factors and university support systems without a meaningful integration.

International students are a diverse group, but they have often been spoken about in academic literature and in academic conversations as an entity, rather than as individuals with a range of personal histories and experiences, and a range of personal motivations and desires (Koehne, 2005). The dimensions of international students' adjustments have been described in multiple

\footnotetext{
${ }^{1}$ Bartell, M. (2003) notes that recent global, competitive environmental forces have created unprecedented challenges for higher education institutions to internationalize, owing to the instantaneity in communication and rapid advances in transportation which result in an increased need for intercultural and international understanding and knowledge.
} 
ways, ranging from academic, social-cultural, interpersonal , financial, linguistic, psychological and practical-e.g. Food, housing and transportation (see Tomich, et al. 2003, Al-Sharideh \& Goe (1998), Koehne 2005, and Hsieh,2006). In all of these studies, the international student is always the site and object of analysis where the nature of their experience is located within the students' strengths and weaknesses. Most of these studies tend to address the factors of international students' experiences from a deficit view of international students as bearers of problems who come with limited language proficiency, minimal independent and critical thinking skills and needing to adjust to our academic system. ${ }^{2}$ Very little is written about how the social, cultural and structural contexts of host institutions prepare to accommodate the diversity of international students and the material and experiential realities of these students as they navigate their ways through our school systems. In the US context where higher education has historically been marked by racial tensions and other forms of institutional stratifications, we need to understand how students lived experiences within and outside the school environment affect their engagement with and disengagement from that environment. This paper is an effort to do just that. It examines how systemic racism in US institutions affects the lived experiences of female African students at a major research university. I focus particularly on how the practice of "networking"(understood here as the practice of forming alliances for intended returns or benefits) in higher education is influenced by systemic racism and how such a practice excludes or marginalizes students from racial minority backgrounds.

\section{NETWORKING IN HIGHER EDUCATION}

The phrase "it's who you know, not what you know that counts" is often heard in conversations about people who get ahead. In academic circles, this concept translates into what is often called "networking". The daily life of the graduate student in US universities hinges on the individual's ability to interact and form strategic alliances with other members of the academy. Indeed, networking is a widely accepted norm within higher education and commonly practiced by well meaning progressive scholars in the academy; but few, if any, have examined the ability of such a practice to exclude certain groups and individual students from active academic participation. It is very common to hear scholars' advice students and especially junior faculty, to try to "network" with particularly the "well connected" and "powerful" scholars in their fields of study. But what exactly does networking entail? What are the factors that influence people's networking practices and how do these factors favor or disadvantage individuals or groups in the networking process?

Similarity breeds connection! This principle is known as the homophily principle, which structures network ties of every type including different ties in higher educational institutions. The principle of homophily asserts that people who are similar to one another along certain socio-demographic dimensions are more likely to interact than people who are dissimilar (McPherson, Popielarz, and Drobnic 2001). Common sense and casual observation tell us that social groups are not random samples of people. Blau (1977) has argued that sociodemographic dimensions such as age, sex and education shape the social interactions between individuals in society. Depending on the processes of historical and institutional constructions, each society structurally provides unequal opportunities to members of different groups defined over race, gender, and class. Several empirical studies have shown a direct relationship between network characteristics on socio-economic standings (Huang and Tausig 1990. see also, Lin, 1999a, 2000). In a study about how network systems affect people's social capital, Nan Lin (2000) observes that significant differences appear in the social networks and embedded resources between females and males. In a similar study, Lin (1999) notes that

${ }^{2}$ Carroll, J. \& Ryan J. (2005). Teaching international students: Improving learning for all. New York: Routledge 
inequality of social capital occurs when a certain group clusters at relatively disadvantaged socioeconomic positions.

In Lin's analysis;

"Social groups (gender, race) have different access to social capital because of their advantaged or disadvantaged structural positions and associated social networks. Situated in different positions in the social hierarchy, and given the tendency to interact with other members of the same social group, members of a disadvantaged group may find themselves deficient in social capital. Inequality in social capital, therefore, can be accounted for largely by structural constraints and the normative dynamics of social interactions"(2000, p.793).

In US higher education, there is an expectation that individuals should be able to "network" with others. The structure of these institutions is such that almost everything ranging from class exercises/assignments to resource allocation to research publications center on this practice. Part of the requirements of graduate study involves students' selection of a committee of faculty to work with during the different stages of their programs. But the reality of the process of networking in the United States is not devoid of the historical tensions that revolve around race, gender and class relations and other forms of divisions.

According to McPherson, Smith-Lovin and Cook (2001), race and ethnicity are the biggest divide in social networks today in the United States and they play a major role in structuring the networks in other ethnically diverse societies as well. In their view,

"the baseline homophily created by groups of different sizes is combined with the differences in racial/ethnic groups' positions on other dimensions (e.g. education, occupation, and income) and the personal prejudices that often result from the latter to create a highly visible, oft studied network divide"(p.420).

Homophily limits people's social worlds in a way that has powerful implications for the information they receive, the attitudes they form, and the interactions they experience.

In an analysis of the significance of race in predominantly white US universities, Joe Feagin(2002) observes that despite the general ideal of the university as a place where knowledge can be exchanged among diverse populations without narrow-mindedness, intolerance and discrimination, the everyday realities of students of color on predominantly white universities portray a picture far from universities as "seats of wisdom and light of the world". Even though the demographic landscapes of colleges around the country are changing: a welcome trend that indicates a growing embrace of diversity by colleges, John Garland (2002) still observes that "higher education often focus on the formal aspects of diversity while permitting all of the substantive evils associated with chauvinistic attitudes to continue to thrive" (p. 38). He notes that the academy has focused on bringing more faces of color onto our campuses without paying attention to "the quality of their experiences, which includes stereotyping and other behaviors that have negative effects on people of color on our campuses" (p.38). So in order to understand how female African students in US universities and colleges negotiate their daily interactions with professors, students and staff, it is important to examine how the structural constraints and normative dynamics of social interactions and their socio-demographic dimensions as black, female and foreign students affect their experience. 


\section{SYSTEMIC RACISM ${ }^{3}$ : A THEORETICAL FRAMEWORK}

Jeo Feagin's research on race relations in US society asserts that the social foundation of US society is historically built on "white-on-black oppression" (2006, p.6). This long term racial oppression in his view is grounded in discrimination and consequent inequity. It has generated a racial ideology that accents the superiority of white Americans over all other racial groups (2002). According to him, white oppression of African Americans is archetypal because it is the original model on which whites' treatment of other non-European groups entering later into the sphere of white domination has largely been patterned" (2006 p. xi). US racial hierarchy, Feagin observes, is based on a continuum that "runs from the privileged white position and status at the top to an oppressed black position and status at the bottom, with different groups of color variously positioned ...." (p. 21).

Systemic racism according to Feagin, "encompasses a broad range of racialized dimensions of the US society: the racist framing, racist ideology, stereotyped attitudes, racist emotions, discriminatory habits and actions and extensive racist institutions developed over centuries by whites" (2006 p. xii). White racial frame is central to the persistence of systemic racism. He defines this frame as "an organized set of racialized ideas, stereotypes, emotions and inclination to discriminate"(p.25). This white racial frame provides a structural skeleton on which thought and action emanates. Most White Americans' racial frame includes negative stereotypes, images and metaphors concerning African Americans and other Americans of color on the one hand, and an assertively positive view of whites. This frame provides an encompassing conceptual and interpretive scheme that shapes and channels assessments of everyday events and encounters with other people (Feagin, 2006:p.26).

African students, like other groups of international students, arriving in US institutions are also positioned within this scheme of social interaction. Regardless of the interpersonal, socioeconomic and linguistic qualities that international students bring to their education in the US, a full understanding of their adjustment experiences requires an analysis of the institutional contexts in which they study. My focus in this paper especially is on how this racial frame shapes the networking process and experiences of female African students in a major university in the US.

\section{RESEARCH METHODS}

The data for this paper is drawn from a pilot study of my dissertation topic on the experiences of female international students in US higher education. I interviewed a total of 18 female international students (12 of whom were African, 2 Indian, 3 Chinese and 1 Korean) over a period of three months during the spring and summer of 2005. For this paper however, I draw on the accounts of the African women but where necessary, I use excerpts from the other women to show where there is similarity of experience. I recognize that my use of "African" to represent these individual women from different countries in Africa is problematic to some degree. But in the US context, they are viewed as a group of black, female foreign students. I therefore use it in this sense to define them as a group who share a common experience in US institutions.

I decided to adopt an open- ended, informal style of questioning about their everyday life "stories" in my interviews. Prior to the interviews, I had engaged in informal conversations with most of the women regarding my desire and purpose of the project, pointing out that I

${ }^{3}$ Feagin, J. R. (2006). Systemic Racism: A Theory of Oppression. New York: Routledge. This conceptual framework explains the centuries of white dominated oppression of blacks and other racial groups in the US. 
was interested in sharing my own experiences with them so that together our common "patterns of experiences" will emerge from the discussions. Through these informal conversations I was able to develop significant rapport with the women as well as develop major themes on which subsequent conversations during the interviews were tailored.

\section{SYSTEMIC RACISM AND AFRICAN WOMEN INTERACTIONS. White Racial Frame and African women's networking}

White domination is often rationalized by the belief that the inferiority or superiority of a group's abilities, values, and culture are linked to their physical characteristics such as skin color" (Feagin, and Sikes 1994; p. 4). Being black, female African students cannot escape the negative stereotypes among white professors and students about black inferiority so engrained in the US society. Such perceptions are often revealed in the differential treatment and responses toward African students by professors especially in classrooms. In their analysis of black students' experiences in predominantly white colleges and universities, Feagin, Vera and Imani (1996) observe that "the subtle and overt distinctions that are made in everyday interactions define the character of the social position one occupies in interaction with others" (p.94). In my interviews with female international students, this theme was echoed by many. An African woman describes her experience of indifference and marginalization in a graduate seminar taught by a white professor.

"I took this seminar on research methods with this guy....it was just three of us out of 11 students that were not white. The two of us who were black, one was an African American guy and the other student was Asian looking, she could have been biracial...I don't know that for sure, but I could tell by her Americanized accent that she probably was born here or grew up here...but anyway, it was just the three of us from non-white backgrounds. For the first six to eight weeks, I realized this man ignored every comment or contribution I made in class. Any time I raised a point, he will just keep quiet and either ask another student or move the discussion on to another focus. At first, I thought that was just his policy not to affirm or dispute any point of view that students raised, but as the class progressed, I noticed he would heartily commend the good points that the other white kids made but when I make a point, everybody acted like I did not exist in the class. But when the same point that I raised earlier is mentioned later by another student, the professor will make comments like "that was insightful". At first, I thought maybe it was because I spoke in an accent that may not be understood, but as time went by; I just noticed it was a deliberate action to make me feel invisible". (R.I., 5/24/2005)

This student went on to explain how she had to interrupt the discussion one day after a point she had made was ignored by the professor, only for another student to state the same point shortly after and received positive compliments by the professor.

“.... But a few minutes later, another white girl basically repeated verbatim, what I said earlier, and this man went ecstatic with praise for the great insight the girl had...I just couldn't ignore it anymore". (R.I., 5/24/2005)

To some white professors, the African woman in graduate school is nothing more than an accident of some diversity and or affirmative action policies. Unlike African American women who are vied as domineering, African women are perceived by white professors as timid and subdued creatures who lack self confidence and initiatives; two key ingredients necessary for a successful graduate study. A senior faculty in the college of education once told me during an interview for a research assistantship he advertised, that he finds it difficult to believe that African women can be self directing since they have lived all their lives under the yokes of their fathers and husbands. 
“.... You know this job requires self initiative and motivation (he said) and I find it difficult to imagine that the spirit you show here today can be sustained.... hardly come across African women and ....I think it's a total waste of resources to fund such women since their only purpose is to serve their husbands and give birth to numberless children".

It may be that this particular professor is just downright nasty and his actions may not reflect the majority who work with African students daily. But even the attitudes of well meaning professors sometimes convey nothing more than a lack of interest. Describing some of her experiences, an African student mother of three notes;

"you know, some times I don't know what to call the reaction that I get when I meet with some professors. You probably have faced such a thing before.... where you go to meet with a professor, and after saying what you want to say for about 3 minutes, you get this attitude of 'what did you say'? .... It looks like as soon as you start to speak, they tune off their ears and minds.... In total black-out until you are done, then they turn back on as if they just recovered from some trance".

This "zoning out" attitude as some of us call it has become a common experience for many African women in US graduate schools.

African women in US institutions often have to contend with the burden of representing "all things African" in class discussions. Similar to the experiences of black American students in white colleges discussed by Feagin, and his colleagues, African women often find themselves in situations where they have to act as "defenders and explainers of their group"(Feagin, Vera, and Imani 1996). When white professors attempt to include minority students into class discussions, it is often done in ways that place enormous pressure on minority students to represent their entire social group as one African woman notes:

"I had this class where the professor will always ask me how do people in Africa do this or that....even when the issue is basically a general idea. I find it ridiculous that this woman would think that there is an African version to everything. I had to point out some day that examples I may give cannot even be representative of my country let alone the entire continent"(RI: 6/27 2005).

What is interesting in the case of these women is the fact that their experiences are not only limited to their interactions with whites. Other non-European international students have come to share in the racial frame of blacks as intellectually inferior to others. One of my respondents shared her story about her friendship with a Chinese student;

"I once had a Chinese course mate ask me why African students are not as "smart", even though I had just finished rewriting her essay for her research specialization. I asked her what she meant by Africans not being smart and she pointed to the fact that there are no Africans doing the 'hard subjects' like engineering and science. I got so upset that day...." (R.I. 6/21/2005)

Although these accounts may point to individual prejudices and bigotry, it is obvious that such feelings, biases and stereotypes are widespread and ultimately influence the individual's ability to form meaningful alliances with others within the institution.

\section{SYSTEMATIC DISCRIMINATION AND AFRICAN WOMEN.}

In their work on how black middle class experience life in white working environments, Feagin and Sikes (1994) observe how subtle forms of exclusion work to bar blacks from professional positions. Quoting Thomas Pettigrew, they note that "racial discrimination is basically an 
institutional process of exclusion against an out-group on largely ascribed and particularistic grounds of merit" (p.19). While whites may have the power to discriminate as individuals, they argue, much of their power to harm comes from membership in white-dominated organizations and social networks.

In one respondent's statements in their work,

"you may move into an environment and not know the rules, and therefore not know how to play the game and not know how to succeed.... the barriers and obstacles are often that people will not allow you into the inner circle. ....the students who get the best grades are the students who know how to talk to the law professors. They know how to call on their fathers, brothers, and uncles to introduce them into the profession...." (Feagin and Sikes, 1994. p,141)

Like the respondent quoted above, African women experience similar exclusion from the inner circles within and outside of their departments. For these women however, the discrimination and racism they face is not only in the hands of white professors, students and staff as one respondent notes, "you would think that it is only whites who are always racists, but I can swear that the African Americans and Latinos are more vicious and blatant in their disdain for us than the whites".

This particular student goes further to explain the difference between "white racism" and "black racism" towards African students.

"the difference is that, for white professors and students, you are often seen as not smart enough to be in graduate school; let me even say that you are not considered to be human, you don't exist!...and when you have an occasion to proof that you might even be smart, you are still a backward person in their mind. But for the African Americans, you are often seen as a threat to their material and economic resources. You often hear comments like 'we(African Americans) fought for affirmative action only for you (Africans) to come and enjoy after you sold us(African Americans) out as slaves'. So because they believe that the benefits of what their ancestors toiled for should be reserved for only African Americans, they feel resentment that we are here today and some even think that we are better treated by the whites than they are". (R.I.: 6/19/2005).

It seems to me from the accounts of these women that while African women may experience discrimination from both white and black American professors and students, the reasons or motivations behind these actions differ between whites and blacks. On the one hand, whites view these women as inferior and not graduate material to work with. On the other hand, blacks see them as competitors over resources and opportunities they (African Students) do not deserve. Among other international students also, they are perceived as inferior; a view similar to the white group. All of these perceptions and actions overall limit mutual interactions and increase suspicion and tension between African women and other members within the academy. How this affects these women in how they network is the focus of the ensuing section.

\section{NETWORKING AND AFRICAN WOMEN}

Graduate study in the US is structured in such a way that individuals have to form or belong to some kind of group in order to survive. From class discussions or assignments to research assistantships to forming academic committees, students have to form alliances with other individuals in order to succeed. Unlike African American students in predominantly white institutions, African women do not usually have such avenues or organizations like study 
groups, sorority groups or black cultural houses in which to interact and network with other African, or American students of color in order to develop effective coping mechanisms for their environment. In a situation where professors hold negative stereotypes about certain groups of students, it becomes difficult for such students to get closer to professors and for the professors to know the actual strengths and weaknesses of the students.

A general tendency in networking however is for individuals to interact and share sentiments with others who have similar characteristics (Lin 1982). Although African students in general are viewed in US institutions as a group, they vary greatly in language and cultural and almost every other demographic feature except the color of their skin (which is also questionable). In fact, when it comes to similar characteristics and the principle of homophily, African women are no more similar among themselves than they are to other racial groups in the US. So the idea that they are more likely going to network with other African students is a far fetched one. A sixth year graduate student succinctly describes this experience thus;

'it is not easy to discuss such painful experiences with other African students because, we all come from different countries in Africa and you know we also have our own ethnic tensions that we bring along to this country".

In most cases, the individual's encounter with racism is often viewed by others as personal weakness of the person and may lead to further isolation and humiliation by other African students.

Overall, US higher education institutions are beset with racial and other forms of stratifications which affect the nature of interactions between groups of individuals. The limitations in mutual interaction in turn influence the nature of ties individuals' form which often turns out to be homogenous (comprising members from similar racial-ethnic and often gender backgrounds). This within group similarity prevents

This relationship between systemic racism, networking and female African students' interaction with other members within higher education institutions is further summarized in the conceptual model below. 
Networking

- Hard to form academic committees

- Participate in discussions

- Form mutual friendships with

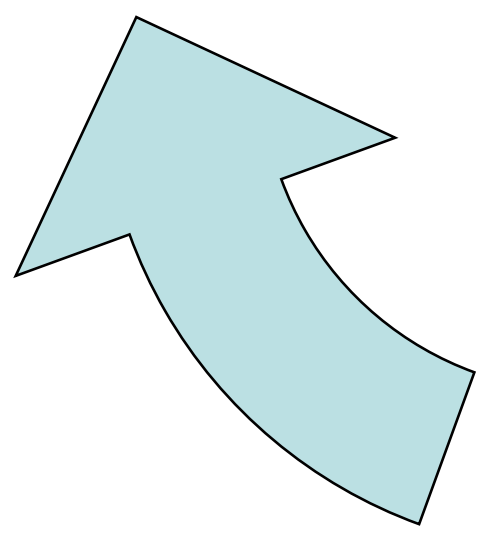

\section{Female African} Students' interactions.

- Negative attitudes of Professors

- White and black students

- international students
Systemic Racism

- racist framing

- stereotyped attitudes

- discriminatory habits/actions

- racist institutions

\section{NETWORKING OR NEPOTISM: WHERE IS THE LINE?}

Nepotism in this paper is understood as favoritism or preferential treatment by people in power extended toward relatives. These may include friends and friends of family. Considering that resources, opportunities and rewards in higher education are distributed based on individual network ties, and bearing in mind that these ties are not necessarily open to anybody that wishes to join, I think it is fair to argue that networking in academic institutions is similar if not tantamount to nepotism. If as McPherson et al (1992) note, race and ethnicity are the biggest divide in social networks today in the United States, it will be a daunting task to say the least, for African women to form meaningful networks because, they are women, often mothers, mostly poor or from geographically poor locations, and black.

As Picca and Feagin(2007) note, discrimination often deny the existence of a structural problem and focus on reforming the victims or their cultural values. In a system that historically has denied people access to resources based on ascribed or constructed characteristics, it is dangerous if not hypocritical to blame international student's experiences on their cultural values or linguistic competence for what the structural arrangements have caused. In the current context of systemic racism in US higher education institutions, an adherence to the idea and practice of "networking" only works to exclude minority student populations from the material and social resources necessary for a successful education. 
Networking in the context of a segregated structure is nothing less than an institutionalized form of nepotism.

\section{References}

Al-Sharideh, K. A., \& Goe, R. W. (1998). Ethnic communities within the university: An examination of factors influencing the personal adjustment of international students. Research in Higher Education, 39, 699-725.

Blau, P. M. (1977). Inequality and heterogeneity. New York: Free Press.

Carroll, J. \& Ryan J. (2005). Teaching international students: Improving learning for all. New York: Routledge Feagin, J. R. (2006). Systemic racism: A theory of oppression. New York: Routledge.

Feagin, J. R. (2002). The continuing significance of racism: U. S. colleges and Universities. Washington D.C.: American Council on Education.

Feagin, J. R. (2000). Racist America: Roots, current realities, future reparations. New York; Routledge.

Feagin, J. R., Vera, H. and Imani, N. (1996). The agony of education: Black students at white colleges and universities. New York: Routledge.

Feagin, J. R. and Sikes, M. P. (1994).Living with racism: The black middle-class experience. Boston: Beacon Press.

Feagin, J. R. and O'brien, E. (2003). White men on race: Power, privilege, and the shaping of cultural consciousness. Boston: Beacon Press.

Freeman, L. C. (2004) The Development of Social Network Analysis: A Study in the Sociology of Science. Vancouver: Empirical Press.

Galloway, F. J., \& Jenkins, J. R. (2005). The adjustment problems faced by international students in the United States: A comparison of international students and administrative perceptions at two private, religiously affiliated universities. NASPA Journal, 42, 175-187.

Garland, J. W. (2002) Response: "What will our students remember" in The continuing significance of racism: U. S. colleges and Universities. Washington D.C.: American Council on Education. Pp. 37-39.

Golde, C. M. (2005). The role of the department and discipline in doctoral student attrition: Lessons from four departments. Journal of Higher Education,76, 669-700.

Hsieh, M. H. (2006). Identity development of East Asian female international students with implications for second-language higher education. Education, 127, 3-15.

Huang, G. and Tausig, M. (1990). "Network Range in Personal Networks." Social Networks 12: 261-68.

Koehne, N. (2005). Reconstruction: Ways international students talk about their identity. Australian journal of education, 49, 104-119.

Lin, N. (2000). Inequality in social capital. Contemporary Sociology 29: 785-795.

Lin, N. (1999a). Building a network theory of social capital. Connections 22:1-24.

McGivney, V. (1996). Staying of leaving the course: Non-completion and retention of mature students in further and higher education. Leicester: NIACE.

McPherson, M., Smith-Lovin, L. and Cook J. M. (2001). Birds of a feather: Homophily in social networks. Annual Review of Sociology, 27, 415-44.

McPherson, M., Popoelarz, P. A. and Drobnie, S. (1992). Social networks and organizational dynamics. American Sociological Review, 57, 153-70.

Picca, L. H. and Feagin, J. R. (2007). Two-faced racism: Whites in the backstage and frontstage. New York: Routledge.

Portes, A. (1998). "Social capital: Its origins and applications in modern sociology". Annual Review of Sociology 22:1-24.

Senyshyn, R. M., Warford, M. K., \& Zhan, J. (2000). Issues of adjustment to higher education: International students' perspectives. International Education, 30, 17-35.

St. Jean, Y. and Feagin, J. R. (1998). Double burden: Black women and everyday racism. New York: M. E. Sharpe. 
Tomich, P., McWhirter, J. J. \& Darcy, M. U. A. (2003). Personality and international students' adaptation experience. International education, 33, 22-39.

Wang, Y. (2004). Pursuing cross-cultural graduate education: A multifaceted investigation. International Education, 33, 52-72. 